\title{
Education and Poverty Linkage in Malawi: A District Level Analysis
}

\author{
Steven Henry Dunga \\ School of Economics Science, \\ North-West University, Vanderbijpark, South Africa \\ Email: stevedunga@gmail.com \\ Mmapula Brendah Sekatane \\ School of Economics Science, \\ North-West University, Vanderbijlpark, South Africa \\ E-mail: brendah.sekatane@nwu.ac.za
}

Doi:10.5901/mjss.2013.v4n14p213

\section{Abstract}

The need to reduce poverty in all its forms remains a priority around the world. The fact that countries with higher incidences of growth have an associated reduction in poverty levels is uncontested both in theory and in empirical findings. The channels through which growth results into poverty reduction are not clear. This study looks at education as a channel through which economic growth and poverty reduction are linked. Using data on districts in Malawi, we estimate a regression with the headcount poverty as a dependent variable and education at different levels as independent variables. The results show that there is a significant relationship between education qualification and poverty reduction at district level in Malawi. MSCE qualification has the highest coefficient, meaning that policies that would encourage attaining an MSCE (O-level equivalent) would have a more significant impact on poverty reduction than just attaining primary level qualification

Keywords: Poverty, education, growth, MSCE'1, Malawi

\section{Introduction}

Poverty as seen from all angles and dimensions remains a problem across the globe, and it is more serious in sub Saharan Africa. The need therefore to reduce poverty in all its forms remains a priority for most countries (Hull, Understanding the relatioship between Economic Growth, employment and Poverty reduction, 2009; Aigbokhan, 2008). There are a number of ways agreed upon in theory as drivers of poverty reduction. These include economic growth (Dollar \& Kraay, 2000;2001), especially pro poor economic growth, as agued by Kakwani et al. (2000) and Bigsten and Shimeles (2003) among others. The promotion of income equality is also considered a useful ingredient in dealing with poverty according to studies by Bourguignon (2000) and Aigbokhan (2008) in Nigeria. Education attainment and increase in participation in formal education is also considered as one way of dealing with poverty in the developing countries where the common picture is that of low education levels. The fact that countries with higher levels of education achievements have associated lower levels of poverty is clear in the literature (Dollar \& Kraay, 2002; Hull, 2009).

Higher levels of education enrolment in school and hence a resultant higher level of education achievements can be a result of lower parental poverty levels where parents or households have enough incomes to invest in their children's education (Adetanwa Aina \& Olabisi, n.d.; GoM, 2008; Rahman, 2006). The link between education and poverty reduction is highly accepted especially where children from poor households have access to education, and to a greater extent where the educated youth have access to employment (Rahman, 2006, p.3). There are a number of countries that have put education forward in an effort to increase participation with the hope of a resultant poverty reduction. A number of countries for example have introduced free basic education, countries like, Kenya and Malawi.

These efforts emanate from the Jomtien conference of 1990 commitments and the Millennium development goals. Malawi is one of the countries that signed the Millennium Development Goals (MDG) with one of the goals being education for all by 2015. With a population of 13 million people in 2008 the country has a huge need for education

${ }^{1}$ Malawi School certificate of education, it is a the certification given when one passes the National examination administered in Form four, an equivalent of O-level 
especially for its young population with 54 percent of the total population under the age of 18 years (ICEIDA, 2012, p.12) a good education policy that can see a good number of young people enrolled in school is expected to have a bearing on poverty in the long run. This paper is therefore set to establish the extent of the relationship between education and poverty rate at district level.

The introduction of free primary education in1994 in Malawi was on the basis that poor people are being left out of school, and that with free access to primary education, it would open a way for them to acquire some education and probably offer a way of escape out of poverty (Chimombo, 2005). There are also other studied like (Psacharopoulos G. , 1994) that found that there are returns that are associated with basic education. This paper looks at the linkage between poverty and education achievement at district level in Malawi.

\section{Literature Review on education and poverty}

The Human capital theory which looks at education as an investment the same way people invest in physical capital provides a basis for the link between education and poverty reduction. The human capital implies that an effective antipoverty strategy should incorporate the enhancement of education and skills. Becker (1964) and Blaug (1970) contended that education embodies skill and attitudes in human beings that make them to become more productive in the work place. Although emphasis in the human capital theory has been laid on the formal sector of employment, the informal sector of self-employment and agriculture has also positive correlations with education. In the Malawi Integrated Household Survey 23 (IHS 3) where the data for this study heavily relies on, it is stated that education is a building block for human, political and socioeconomic development, particularly important for poverty reductions because it empowers the poor, the weak and the voiceless by providing them with better opportunities to participate in national development (NSO, 2012).

Another link between education and earning hence reduction in poverty is postulated in the mincerian earnings function. The Mincerian Earnings Function links earnings of individuals to years of schooling according to Mincer (1974). Through the mincerian function years of schooling have been found to be a significant factor in explaining the different levels of earnings people with different education levels have (Polachek, 2007; Hayne \& Michelle, 2004). The link between education and poverty reduction is one that has also arguments on the other direction. There are studies (Dunga, 2012; Hull, Understanding the relatioship between Economic Growth, employment and Poverty reduction, 2009) that have argued that education can also be blamed for the increasing inequality in other societies, where only the rich have access to better education and the poor have no access and hence propelling the vicious circle of poverty. The relationship between poverty and education is particularly important because of the key role played by education in raising economic growth and reducing poverty. However the overwhelming evidence in the literature point to the fact that the better educated have higher incomes and thus are much less likely to be poor (Psacharopoulos G. , 1994; Siphambe, 2000; WorldBank, 2010).

Much of the debate about the role of education in development and economic growth has focused upon whether education is productive in an economic sense as argued by Oxaal (1997). There is much evidence that levels of schooling amongst the population are highly correlated with levels of economic development. But whether the former has helped cause the latter, or whether causality runs from income growth to educational expansion, remains open to debate Human Capital Theory (associated with the work of Gary Becker, Mark Blaug and many others), asserts that education creates skills which facilitate higher levels of productivity amongst those who possess them in comparison with those who do not. Education, then, although costly brings associated benefits which can be compared with its costs in much the same way as happens with any investment project according to Blaug (1970) Schultz (1960) and Johnes (1993).

One of the important things that can be looked at is that there is a strong, and empirically verifiable, positive relationship across all societies between the wages and salaries people receives at work and the level of education which they have received. This may not reflect productivity but it is assumed that those with higher education bring with them specialised skills hence deserve a higher pay. This then can be argued as pointed out by Oxaal (1997) that using the normal assumptions of competitive labour and goods markets, it follows that those with higher levels of education seem to have, on average, higher levels of productivity. Employers use educational characteristics as a proxy for the suitability, and potential productivity, of their employees. Education is also used as a screening too in deciding who to be hired. Another clear indication of educations importance to the level of earnings is that, the earnings by age of the more

\footnotetext{
2 This is a national wide survey conducted by the national statistics office of Malawi. It has the highest representation of households and it covers all the districts in the country. there have been three rounds so far, known as IHS1, IHS2 And IHS 3
} 
educated not only start at a higher level, but increase more rapidly to a peak as they progress in their career. This is different with the earnings profiles of the less educated whose earnings profiles remain to a greater extent flat throughout their lives (Blaug, 1979; Johnes 1993 Oxaal 1997).

There are however other characteristics of education that needs to be noted, which to a greater extent are similar to what happens to physical capital. The fact that the profiles peak and then decline beyond a certain age suggests that the skills created by education are prone to obsolescence and that their productive value declines when technology has changed beyond the embedded knowledge (Polachek, 2007). An extremely important context, however, for a discussion of poverty is that part of production which takes place outside the formal sector, much of which is characterised by selfemployment in rural and peri-urban areas and has a different form of education and skills which is not recognised by the formal education accounting. There has therefore been much interest in examining the extent to which education affects production patterns in those activities.

It has been shown that primary schooling, for example, helps to increase the productivity of subsistence and low rural area farmers, particularly when they have access to the other inputs needed to enhance their production. It has been shown also that the earnings of the self-employed, including those in urban and informal sector activities, are to some extent higher for the educated than for the uneducated. to this end other studies have demonstrated that increasing the schooling of women brings beneficial effects for their own control of fertility, for their own health, and that of their families according to Oxaal, (1997). The need to find to what extent education has influenced the movements of the poverty rate at district level in Malawi therefore is based on this premise, with the apriori expectation that the districts with higher education level will have a resultant lower poverty rate.

\section{Methodology}

The regression estimated used district poverty rate as a dependent variable, where it was expected that the levels of education in the district will have an impact on the overall district poverty. Below is the linear regression model;

$\mathrm{DPR}_{i}=\beta_{0}+\beta_{1}$ Educrt $+\beta_{2}$ Prim $+\beta_{3} J c+\beta_{4} M S C E+\beta_{5}$ Tert $+u_{\ldots \text { (1) }}$

Where DPR is the District Poverty Rate (DPR), Educrt is the district education rate which is a percentage of people that have some level of education. 100 - Educrt gives the percentage of people that don't have any education at all, this is the district uneducated rate. Prim is the percentage of people that have a primary education, JC is the percentage of people that have a Junior certificate in the district, Malawi School Certificate of Education (MSCE) is the percentage of people that have an MSCE certificate which is an equivalent to O-levels, and Tert is the percentage of people that have a tertiary qualification in the district.

\subsection{Data}

Data used in this study was collected by National Statistics Office (NSO) of Malawi between 2010 and 2011 under the IHS 3 (NSO, 2012, p.1). The Survey is a nationally representative sample survey designed to provide information on the various aspects of household welfare in Malawi. The survey collected information from a sample of 12,288 households statistically designed to be representative at both national, district, urban and rural levels. The data used in this paper are district aggregates.

\subsubsection{Descriptives}

Table 1: Literacy rates

\begin{tabular}{|c|c|c|}
\hline Group & 2004 & 2012 \\
\hline Male & 76 & 74.4 \\
\hline Female & 52.4 & 57.2 \\
\hline Malawi & 65 & 65.4 \\
\hline
\end{tabular}

Source: IHS 3 (2012)

Table 1 above presents the literacy figures for the two main rounds of Integrated Household Surveys (IHS) 2 and 3. These figures are necessary as they will offer a basis for comparison and better analysis in looking at the qualification figures. There will obviously be differences between literacy rates and qualification emanating from the fact that some 
people drop out of school before they get a qualification.

Table 2: Education level percentages at district level

\begin{tabular}{|l|c|}
\hline \multicolumn{1}{|c|}{ Education level } & Percentage for all districts \\
\hline No qualification & 72.7 \\
\hline With a qualification & 27.3 \\
\hline Total & 100 \\
\hline
\end{tabular}

Source: Author based on IHS 3 (2012)

There are more people with no education qualification in Malawi than those with a qualification. Table 2 above shows that 72.7 percent of the people in the sample had no education qualification. This however is different from the literacy rate which is much higher than the 27.3 percent of people with qualifications. Literacy rate which is defined by those who can read and write in Chichewa or English or any other language, was at 64 in 2004 and 65.4 in 2012 for the whole population and 76 in 2004 and 74.4 percent among male (NSO 2004, p.19: 2012, p.23). The difference is due to the fact that not all that can read and write managed to get to the certification grade. In Malawi the first certificate is primary leaving certificate which is issued when one passes the national examination administered in standard 8. Table 3 below further splits the 27.3 percent of people that have an education qualification into the levels of qualification attained.

Table 3: Percentage of people per level of qualification

\begin{tabular}{|l|c|}
\hline \multicolumn{1}{|c|}{ Education level } & Percentage for all districts \\
\hline Primary certificate & 11.5 \\
\hline Secondary Junior certificate & 8.9 \\
\hline Secondary MSCE (O-Level) & 5.28 \\
\hline Tertiary Certificate & 1.28 \\
\hline Total & 27.3 \\
\hline
\end{tabular}

Source: IHS 3 (2012)

To clearly demonstrate the distribution, figure 1 of a pie chart below presents the data in table 3 graphically.

Figure 1: Distribution of qualification

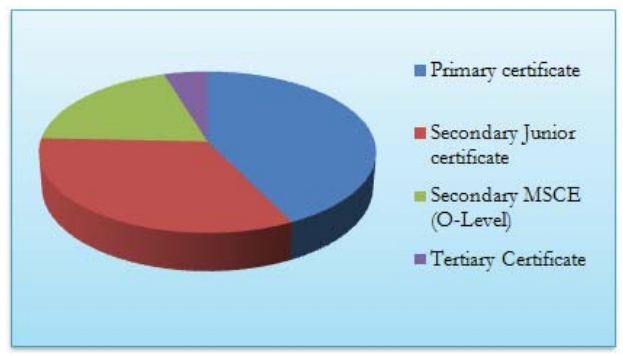

Source: Author based on IHS 3 (2012)

The qualification levels are very low in Malawi, and also they are concentrated at the lower levels. With primary and lower secondary qualification taking close to 75 percent of all the qualifications, it is very difficult to see significant education effect on incomes where education levels are concentrated on the unskilled levels. The regression analysis below is used to estimate the effect of each education qualification on district poverty rate. 


\subsubsection{Regression Results}

The changes in the district poverty rate can be explained by so many factors, education level is just one of them. It is therefore not the expectation in this paper to have full explanation of the variation since only education levels are used. Table 4 below presents results of the OLS regression with District poverty rate as a dependent variable and all the qualifications included as independent variables.

Table 4: Regression 1 with all qualification as independent variables

\begin{tabular}{|l|c|c|}
\multicolumn{1}{|c|}{ variable } & coefficient & \multicolumn{1}{c|}{ p-value } \\
\hline Primary level & -1.773152 & 0.059 \\
\hline Secondary JC & 0.6003206 & 0.625 \\
\hline Secondary MSCE & -0.5604632 & 0.769 \\
\hline Tertiary & -4.92303 & 0.225 \\
\hline Constant & 76.408315 & 0.000 \\
\hline
\end{tabular}

Source: Regression results from STATA

\subsubsection{Dependent Variable - District poverty rate}

The results of regression 1 show that education is a very important explanatory variable of the variation in poverty rate at district level. Although only primary qualification came out significant at 5 percent, it is important to note that the sign of the coefficient are negative indicating that an increase in the percentage of those with a qualification level has an associated decrease in the percentage of poverty at district level. Regressing all qualifications as one independent variable in a simple regression gives a very impressive picture. Table 5 below presents the result of regression 2 and it is significant at 1 percent significance level with the coefficient of -1.070239 , indicating that a 1 percent increase in the number of those with a qualification would lead to a 1.07 percent reduction in poverty rate.

Table 5: Regression 2 with one independent variable, some all certificates

\begin{tabular}{|ccc|}
\hline District poverty rate as dependent variable & coefficient & p-value \\
\hline All certificates & -1.070239 & 0.000 \\
\hline Constant & 79.65403 & 0.000 \\
\hline
\end{tabular}

Source: Regression Results from STATA

A study by Psacharopoulos (1994) that surveyed rates of return on education for 78 countries showed return to primary education ranging from 42 per cent in Botswana to only 3.3 per cent in former Yugoslavia and 2 percent in Yemen. The largest return to secondary was from Zimbabwe at 47.6 percent per annum. It goes on to show that returns to education vary across countries for different levels. Linking education directly to poverty reduction, a primary certificate reduces poverty in Malawi at district level by 1.35 percent as reported in Table 6 below. This can be compared to the results by Dollar and Kraay (2000) where they found that a 1 percent increase in income per capital had a 1 percent reduction in poverty rate. This result can be linked to the mincerian function which states that education levels have a positive bearing of income levels.

Table 6: Regression 3 with primary and secondary MSCE as independent variables

\begin{tabular}{|c|c|c|}
\hline District poverty rate as dependent variable & coefficient & \multicolumn{1}{c|}{$\mathbf{p}$-value } \\
\hline Primary certificate & -1.351606 & $0.052^{\star \star}$ \\
\hline Secondary MSCE & -2.492278 & $0.000^{\text {*** }}$ \\
\hline Constant & 79.22365 & $0.000^{* * *}$ \\
\hline
\end{tabular}

Source: Regression results from STATA

Regression 3 looked at the two most popular levels, where most people in Malawi that have an education qualification are able to attain. The results show that there is a significant relationship, with MSCE having a higher and significant coefficient of -2.492278 and a p- value of 0.000 . Meaning a 1 percent increase in those with an MSCE would lead to a 2.492278 percent reduction in poverty rate at district level. If education was the only needed factor, then policies that would motivate people to get to MSCE would be a very effective poverty reduction strategy. 


\section{Conclusion}

There is a clear correlation between education and poverty reduction in Malawi at district level. The regression analysis shows a significant relationship between primary qualification and secondary qualification, with secondary having a higher impact. Tertiary is even much higher on its impact to poverty reduction with a coefficient of -4.92 but did not come significant. This could be due to the low percentage of people with that qualification level. Increasing education participation is therefore a very positive direction in dealing with poverty. It is however important for students not to drop out on the way but to attain at least an MSCE since this shows to have a greater and significant impact on poverty reduction.

\section{References}

Adetanwa Aina, I. O., \& Olabisi, I. (n.d.). Altenative ways of financing Higher education in nigeria.

Aigbokhan, B. E. (2008). Growth, Inequality and Poverty in Nigeria. Addis Ababa, Ethiopia: United Nations Economic Commission for Africa (UNECA).

Barr, N. (2003, June 10). Financing higher education: Comparing the options.

Becker, G. (1964). Human Capital. New york: Columbia University Press.

Bigsten, A., \& Shimeles, A. (2003). Prospects for 'Pro-poor' Growth in Africa.

Bloom, D., Canning, D., \& Chan, K. (2006). Higher Education and Economic Development in Africa. World Bank.

Bourguignon, F. (2000). The pace of economic growth and poverty reduction. TheWorld Bank and Delta, Paris).

Chimombo, J. P. (2005). Quantity versus quality in education: Case studies in Malawi. International Review of Education(55), 155-172.

Chirwa, E. W. (2004). Access to Land, Growth and Poverty Reduction in Malawi.

Chirwa, E., Kumwenda, I., Jumbe, C., P.Chilonda, \& Minde, I. (2008, October). Agricultural growth and Poverty reduction in Malawi: Past Performance and Recent trends. ReSAKSS Working Paper No.8, International Crops Research Institute for the Semi-Arid Tropics (ICRISAT)(policy Research Institute (IFPRI) and International Water Management Institute (IWMI).).

Chiunda, D. P., \& Gerald. (2010). Tracer study of TEVET and Higher Education Completers.

Docampo, D. (2007). International Comparisons in Higher Education. Working paper.

Dollar, D., \& Kraay, A. (2000;2001). Growth is Good for poor, Development Research group. The World Bank.

Dollar, D., \& Kraay, A. (2002). growth is Good for the Poor. Journal of Economic Growth, 7(3), 195-225.

Dunga, S. (2012). Determinants of primary education Quality in developing countries: factors that matter. London: LAP.

Filmer, D. (2010). Retrieved 03 13, 2012, from http://econ.worldbank.org: http://econ.worldbank.org/projects/edattain

Glewwe, P., \& Jacoby, H. (1994). Student Achievement and schooling choice in low income countries. Journal of Development Studies(32), 554-584.

GoM. (2008). Education sector Implementation Plan 2009-217. Lilongwe: Malawi Governemnt.

Hayne, \& Michelle, D. G. (2004). Financing higher education. International Handbook on the Economics of Education, 298-328.

Johnstone, D. B. (2003). Cost Sharing in higher education: Tuition, Financial Assistance and accessibility in comparative perspsctive. Czech socialogical Review, 39(3), 351-374.

Johnstone, D. B. (2006). Financing Higher education, Cost Sharing in International perspective. New York: York at Buffalo .

Kakwani, N., \& Sajaia, Z. (2004). New poverty Thresholds for Russsia. Unpublished.

Monk, D. (1990). Education Finance: an economic Approach. New York: McGrawHill.

NSO. (2012). Intergrated Household Survey 3 (IHS 3). Zomba: Malawi Government Press.

Oxaal, Z. (1997). Education and Poverty A gender Analysis. Brighton: Institute of Development Studies.

Polachek, S. W. (2007). Earnings Over the Lifecycle:The Mincer Earnings Function and Its Applications. IZA DP No. 3181. Forschungsinstitut.

Psacharopoulos, G. (1985). Education for Development. Washington: Oxford University Press.

Psacharopoulos, G. (1994). Returns to investment in Education: A global update. World Development, 9, 1325-1343.

Rani, P. G. (n.d.). Economic Reforms and Financing Higher Education in India.

Ravallion, m., \& Shaohua, C. (2003). Measuring pro-poor growth. Economic letters, 78(1), 93-99.

Schultz, T. (1961, March). Investment in Human Capital. The American Economic Review, 51(1), 1-17.

Siphambe, H. K. (2000). Rates of Return to Education In Botswana. Economics of Education Review, 19(3), 291-330.

UNDP. (2011). Human Development Report, sustainability and equity: a better future for all. NY: Palgrave Macmillan.

WorldBank. (2010). The Education system in Malawi; Country Status Report. Washington, D.C: Library of Congress Cataloging in Publication Data 